\title{
Perception of local inhabitants regarding the socioeconomic impact of tourism focused on provisioning wild dolphins in Novo Airão, Central Amazon, Brazil
}

\author{
LUIZ C.P.S. ALVES ${ }^{1,2,5}$, CAMILAH A. ZAPPES ${ }^{2,3}$, RAFAEL G. OLIVEIRA ${ }^{2,6}$, \\ ARTUR ANDRIOLO ${ }^{2,4}$ and ALEXANDRE DE F. AZEVEDO ${ }^{1,5}$ \\ ${ }^{1}$ Programa de Pós-graduação em Meio Ambiente, Universidade do Estado do Rio de Janeiro, \\ Rua São Francisco Xavier, 524/12005-F, Maracanã, 20550-900 Rio de Janeiro, RJ, Brasil \\ ${ }^{2}$ Instituto Aqualie, Rua Áustria, 300, 28910-270 Cabo Frio, RJ, Brasil \\ ${ }^{3}$ Universidade Federal Fluminense, Instituto de Ciências da Sociedade e Desenvolvimento Regional, Departamento de \\ Geografia de Campos, Rua José do Patrocínio, 71, Centro, 28010-385 Campos dos Goytacazes, RJ, Brasil \\ ${ }^{4}$ Departamento de Zoologia, Instituto de Ciências Biológicas, \\ Universidade Federal de Juiz de Fora, Campus Universitário, 36036-330 Juiz de Fora, MG, Brasil \\ ${ }^{5}$ Laboratório de Mamíferos Aquáticos e Bioindicadores, Faculdade de Oceanografia, Universidade do Estado do Rio de Janeiro, \\ Rua São Francisco Xavier, 524/4002-E, Maracanã, 20550-013 Rio de Janeiro, RJ, Brasil \\ ${ }^{6}$ Secretaria de Estado de Turismo, Rua Marília de Rezende Scarton Coutinho, 194, \\ Enseada do Suá, 29050-410 Vitória, ES, Brasil \\ Manuscript received on June 25, 2012; accepted for publication on April 3, 2013
}

\begin{abstract}
Botos (Inia geoffrensis) are currently provisioned for use in tourist attractions in five sites in the Brazilian Amazon. Despite the known negative effects associated with human-wild dolphin interactions, this activity has been regulated and licensed in the Anavilhanas National Park in Novo Airão, Amazonas State, Brazil. We present an updated evaluation of the perception of the local community concerning the possible socioeconomic impacts of this tourism in Novo Airão. In April 2011, 45 interviews were conducted with inhabitants. A small segment of Novo Airão perceives currently itself as being economically dependent on the botos feeding tourism. Despite that, the economic benefits of this controversial activity apparently are not shared among most inhabitants, and botos feeding tourism is perceived as generating diverse negative effects. We conclude that if the activity was banned or modified into a less impacting tourist activity, this action would probably not majorly affect the lives of the general population.
\end{abstract}

Key words: Amazon, Anavilhanas National Park, artificial feeding, boto, Inia geoffrensis.

\section{INTRODUCTION}

Both dolphin provisioning and swimming with dolphins, which are promoted as commercial tourist activities, have increased over the past decades, despite the growing number of publications describing theirnegative effects. Human provisioning of wild dolphins as a tourist attraction has become

Corresponding to: Luiz Cláudio Pinto de Sá Alves

E-mail: 1cpsalves@yahoo.com.br controversial (Orams 2002) but continues to occur at many locations; moreover, extensive documentation has shown that feeding by humans is often harmful to the animals and could be dangerous for the humans (reviewed by Orams).

The problems associated with feeding dolphins include changing the animals' diet and homeranging behaviors, problems associated with eating fish that are not fresh, the danger of malevolent 
poisoning and the ingestion of inappropriate foods and encouraging the dolphins to beg for food from people who may take offense (Wilke et al. 2005). Other problems include the alteration of natural behavior patterns and population; dependency and habituation; aggression; health/disease/ injury problems (Orams 2002); an increased risk of human-induced injury, such as boat strikes, entanglement (Donaldson et al. 2010) and most likely ingestion of fishing gear; and deliberate harm. A large number of publications describing the risks associated with swimming with dolphins (for both humans and/or dolphins) also exist (e.g., Shane et al. 1993, Santos 1997, Constantine 2001, Samuels and Bejder 2004).

According to Brazilian law number 9985/2000, the basic objective of a national park is the preservation of natural ecosystems and areas of high ecological importance and scenic beauty; national parks facilitate scientific research, the development of environmental education and interpretation, and appropriate recreational activities related to nature and eco-tourism (Brasil 2000). The artificial feeding of wildlife is a type of activity contrary to the basic objective and functions of a national park. Despite these concerns, there are no specific laws prohibiting wildlife provisioning inside of the conservation units in Brazil. However, provisioning is prohibited by the internal regulations of some national parks (e.g., Serra dos Órgãos National Park; ICMBio 2010). In these cases, individuals who ignore these regulations may be subject to fines. In Brazil, it is forbidden to capture or intentionally disturb cetaceans in Brazilian waters (Federal Law 7643/1987; Brasil 1987). Presidential Decree 6514/2008 (Brasil 2008) article 30 states that the intentional disturbance of any species of cetacean, pinniped or sirenian in Brazilian waters is forbidden, and lawbreakers are subjected to fines. Feeding those animals could be interpreted as an infringement of this article in the decree, and swimming with and touching animals such as dolphins could be similarly interpreted as infringements.
In Brazil, at least five cases of aggregations of wild botos (Amazon river dolphin), Inia geoffrensis (de Blainville, 1817), becoming habituated to human contact for tourism purposes have occurred in Amazonas State, Central Amazon (Alves et al. In press). In the urban area of Novo Airão, the locals have regularly provisioned botos from a floating structure that is located inside the Anavilhanas National Park area. The lack of existing data on how economically dependent the local community has become on this tourist activity has been used as one of the justifications for maintaining these activities in Novo Airão, despite F.C. Romagnoli's (unpublished data) argument that the economic benefits derived from the activity do not extend to the great majority of the inhabitants of the city, and, as a consequence, the benefits are shared by few. In 2010, the process of regulation and licensing activities conducted with the botos at the Anavilhanas National Park began (Vidal 2011), and these initial attempts may be used as a reference to legitimize other existing cases and lead to the spread of this activity to other areas of the Brazilian Amazon.

Dolphins, in particular, have a high degree of public familiarity and desirability as a display animal (Fraser et al. 2006). Novo Airão is located only $180 \mathrm{~km}$ by paved roads from Manaus (the Amazonas State capital) and is currently one of the best-known destinations of tourists visiting the Brazilian Amazon, Manaus and nearby cities. Novo Airão is known worldwide for its naturerelated attractions, including the conditioned botos; moreover, the botos are a cheap attraction that is easily accessible because it is located in an urban area that is a few meters from one of the main streets of the small town.

On the basis of the possible future creation of new interaction sites as tourist attractions in the Brazilian Amazon and the possible negative effects of the spread of this activity in local communities, the main goal of this study is to produce an updated and accurate evaluation of the perception of local 
community regarding the possible socioeconomic impacts of tourism focused on provisioning botos in Novo Airão, Amazonas State, Brazil.

\section{MATERIALS AND METHODS}

\section{STUDY AREA}

The activity of botos provisioning started illegally in 1998 (according to the owner of the wooden floating structure where the interactions occur) inside of the Anavilhanas Ecological Station (a highly restrictive conservation unit that does not allow any type of tourist activity inside its area). The botos are provisioned from a wooden floating structure, which used to be a restaurant, located inside of the Anavilhanas National Park (the Ecological Station was transformed into a National Park in 2008; Figure 1), on the Negro River right margin, in front of the Anavilhanas archipelago.
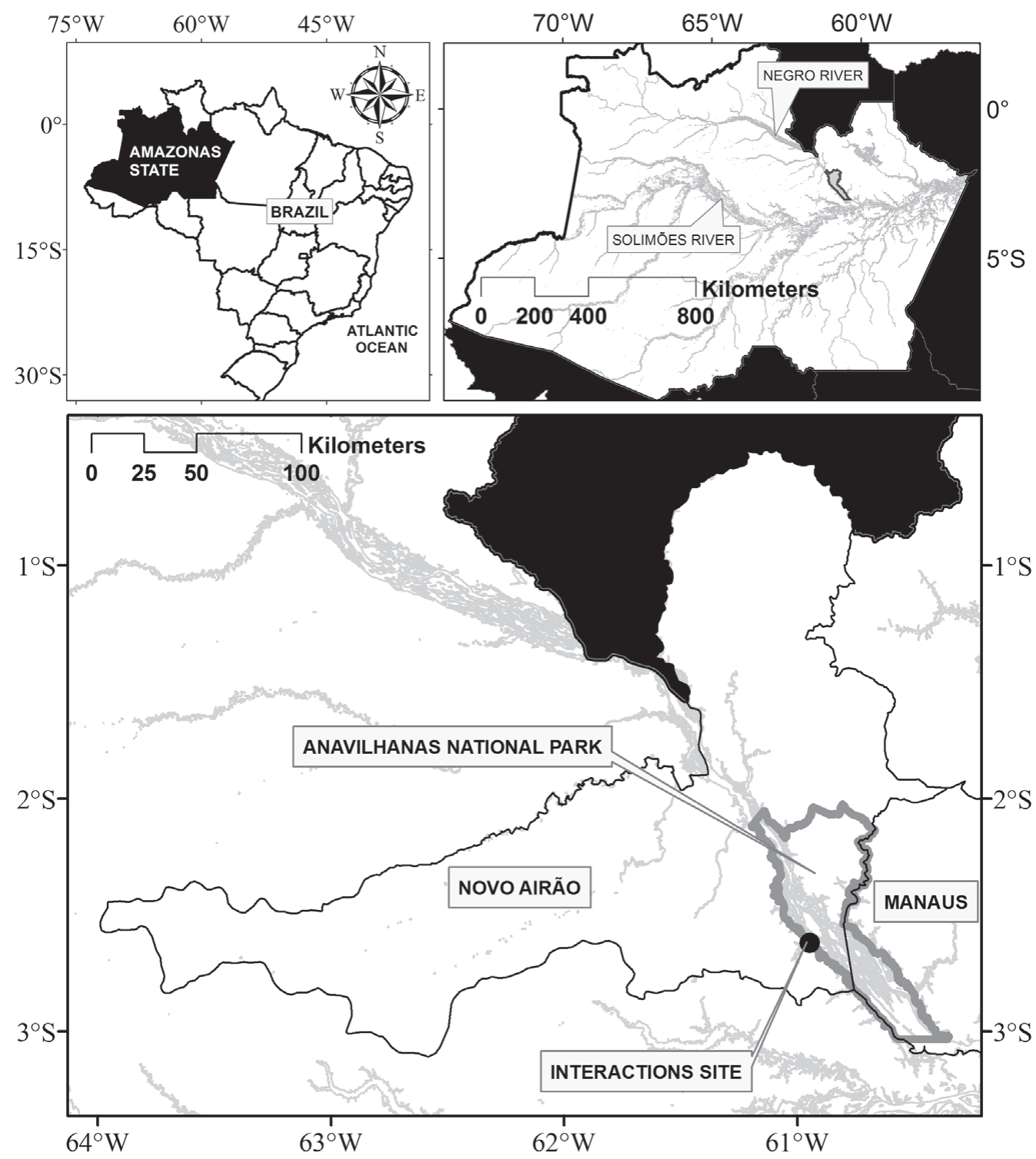

Figure 1 - Upper left: Amazonas State in Brazil; upper right: Anavilhanas National Park in Amazonas State; down: Anavilhanas National Park in the municipalities of Manaus (Capital of the State) and Novo Airão and the interaction site, located in Novo Airão city. 
The floating structure is located close to the main harbor in an urban area located in Novo Airão and it is currently a tourist attraction in the town. Novo Airão is a small town $115 \mathrm{~km}$ northwest of Manaus, capital city of Amazonas State. The population census conducted in 2010 registered a total of 14,723 inhabitants (IBGE 2010).

METHODS

In April 2011, 24 interviews were conducted with inhabitants, and 21 interviews were conducted with local businessmen (a specific segment of inhabitants) from Novo Airão, for a total of 45 interviews. The interviews were guided by standard semi-structured questionnaires (Schensul et al. 1999) containing open and closed questions that functioned as a roadmap for the interview. During most interviews, some questions produced closed responses followed by a justification or open explanation, in which the interviewee would better express his/her thoughts. The interviews were conducted in an informal manner using these questionnaires (Kendall 2008). All interviews were conducted through dialogs that facilitated interaction and the establishment of trust between the interviewer and the interviewee. Some interviews were also recorded using a digital recorder with the permission of the interviewee. The expressions used in the questionnaire were in accordance with the vocabulary that is generally used by the local inhabitants and businessmen, according to previous studies conducted in Amazonas State (L.C.P.S. Alves et al., unpublished data, Alves and Andriolo 2010, Alves et al. 2011, Alves et al. In press).

To test its reliability, confirm the information and validate the data contained in the statements of the interviewees, the technique of using repeated information in synchronic situations was used, in which the same questionnaire was applied to each of the groups (Melo 2004), i.e., the same questionnaire was applied to all of the businessmen and the same questionnaire was applied to all of the inhabitants. The questionnaires used during the interviews with the inhabitants and the businessmen were divided into categories of questions focusing on the interviewee's family's direct relationship: (1) to tourist activities and (2) to the botos provisioning tourist activity; and his/her perception of: (3) the activity in general; (4) how tourism in general and, more specifically, the botos provisioning tourist activity interfere in the socio-economy of the region where they live and in their personal lives; (5) what would happen to Novo Airão and to the interviewee's life if the botos provisioning tourist activity was banned in the near future; (6) how this activity impacts the botos involved; (7) the spread of this activity through the Amazonas State.

The sampling team (two researchers) conducted a random search in the city and interviewed one inhabitant and one businessman. From the second interview onward (in each group studied), the "snowball method" was used whereby potential interviewees (inhabitants or businessmen) were contacted based on information gathered from members who had already been interviewed (Bailey 1982). The researchers introduced themselves and, after a short informal conversation, the researchers asked the interviewee if he/she would participate in a research project focusing on tourism issues in Novo Airão. To avoid possible interference from other persons, the interviewees were always interviewed individually.

After transcribing the interviews, a table was created to organize the data according to categories related to the initial research questions in the questionnaires (Ryan and Bernard 2000). With this table, it was possible to group the information into categories of themes to classify the reports so that the material pertinent to a particular topic could be easily identified, thus facilitating the interpretation of the interviews (Bogdan and Biklen 1994). Through the classification of the statements, it was possible to clarify the relationship between the language and the social interaction by applying an analysis of the discourse (based on Rocha and Deusdará 
2005). Descriptive statistics were gathered during the analysis. An analysis of the differences in proportions was also conducted (utilizing Statistica 8.0 software) to compare the perceptions of both the businessmen and the inhabitants about banning the activity of botos provisioning. A significance value of $p$ less than or equal to 0.05 was used.

\section{RESULTS}

The interviewees were questioned about the existing tourist attractions of Novo Airão. The businessmen $(\mathrm{N}=21)$ mentioned the existence of 25 tourist attractions in the city (Table I). Each businessman mentioned an average of 4.4 attractions, ranging from 1 to 12 attractions. Of the 25 attractions

TABLE I

Tourist attractions mentioned by the local inhabitants and businessmen from Novo Airão, their frequencies and percentages.

\begin{tabular}{|c|c|c|c|c|}
\hline \multirow{2}{*}{$\begin{array}{l}\text { Attractions mentioned/interviewees } \\
\text { Attraction }\end{array}$} & \multicolumn{2}{|c|}{ Businessmen } & \multicolumn{2}{|c|}{ Inhabitants } \\
\hline & Frequency & Percentage (\%) & Frequency & Percentage (\%) \\
\hline Feeding botos & 19 & 20.65 & 22 & 37.93 \\
\hline Artisan handicraft* & 14 & 15.22 & 3 & 5.17 \\
\hline Anavilhanas archipelago & 12 & 13.04 & 7 & 12.07 \\
\hline Jaú National Park & 5 & 5.43 & 2 & 3.45 \\
\hline Airão velho (old Airão city) & 5 & 5.43 & - & - \\
\hline Madadá cave & 4 & 4.35 & - & - \\
\hline Trekking & 4 & 4.35 & 2 & 3.45 \\
\hline Banho do Mato Grosso (Mato Grosso river bath site) & 4 & 4.35 & 8 & 13.79 \\
\hline River beaches & 3 & 3.26 & 1 & 1.72 \\
\hline Fishing & 3 & 3.26 & - & - \\
\hline Carnaboto Festival & 2 & 2.17 & - & - \\
\hline Peixe-boi Festival & 2 & 2.17 & 5 & 8.62 \\
\hline Anavilhanas National Park & 2 & 2.17 & 3 & 5.17 \\
\hline Vipers permanent exhibit & 2 & 2.17 & 1 & 1.72 \\
\hline Dinosaur sculpture & 1 & 1.09 & 1 & 1.72 \\
\hline Student Festival & 1 & 1.09 & 2 & 3.45 \\
\hline Igapos & 1 & 1.09 & - & - \\
\hline Nature & 1 & 1.09 & - & - \\
\hline Hotels & 1 & 1.09 & - & - \\
\hline River boat rides & 1 & 1.09 & - & - \\
\hline Bars & 1 & 1.09 & - & - \\
\hline Local culture & 1 & 1.09 & - & - \\
\hline Natural beauties & 1 & 1.09 & - & - \\
\hline Local people & 1 & 1.09 & - & - \\
\hline City Anniversary Festival & 1 & 1.09 & - & - \\
\hline CAT (Tourist Information Centre) & - & - & 1 & 1.72 \\
\hline Total & 92 & 100 & 58 & 100 \\
\hline
\end{tabular}

* Nine businessmen mentioned artisan handicraft stores/studios as a tourist attraction. Some businessmen mentioned more than one artisan handicraft store/studio. Businessmen mentioned four artisan handicraft stores/studios: Almerinda Malaquias Foundation, Novarte, Waimiri-Atroari (indigenous handicraft store/studio) and Novo Airão's Artisans Association. 
mentioned, 14 (56\%) were linked to nature tourism for a frequency of $63(68.48 \%)$ out of the 92 citations. The inhabitants $(\mathrm{N}=24)$ mentioned the existence of 13 tourist attractions in Novo Airão (Table I). Each inhabitant mentioned an average of 2.42 attractions, ranging from zero (two inhabitants [8.33\%] stated they did not know any tourist attractions in Novo Airão) to six attractions. Of the 13 attractions mentioned, nine $(69.23 \%)$ were linked to nature tourism for a frequency of $46(79.31 \%)$ out of the 58 citations. One inhabitant considered the local tourist information center as a tourist attraction.

Some of the businessmen and inhabitants mentioned the existence of more than one tourism attraction, which explains why the sampling size of the citations is higher than the number of interviewees. Nineteen $(90.48 \%)$ of the businessmen $(\mathrm{N}=21)$ and $18(75 \%)$ of the inhabitants $(\mathrm{N}=24)$ perceived the botos feeding activity as the main tourist attraction of Novo Airão. Some interviewees stated that they did not know the answer (2 businessmen [9.52\%] and 3 inhabitants [12.5\%]). One inhabitant (4.17\%) stated that the main attraction is the whole ecosystem; another one stated that the Anavilhanas National Park is the main attraction, and another stated that the Anavilhanas archipelago is the main attraction. Four $(19.05 \%)$ of the businessmen $(\mathrm{N}=21)$ and five $(20.83 \%)$ of the inhabitants $(\mathrm{N}=24)$ stated that they have family members working in tourism; three (14.29\% of the total) of these businessmen and one ( $4.17 \%$ of the total) of the inhabitants $(\mathrm{N}=24)$ stated that their previously mentioned family members work with activities directly linked to the botos feeding activities.

When asked about what the tourists represent to Novo Airão, 18 businessmen $(85.71 \%$; $\mathrm{N}=21$; 30 citations) and 18 inhabitants $(75 \% ; \mathrm{N}=24 ; 29$ citations) stated that the tourists present benefits; one businessman (4.76\%) and one inhabitant (4.17\%) stated that the tourists do not present benefits, and two businessmen $(9.52 \%)$ and five inhabitants (20.83\%) did not know the answer (Table II).
TABLE II

Perception of businessmen and inhabitants about what tourists represent to Novo Airão.

\begin{tabular}{lcc}
\hline Description* & Businessmen & Inhabitants \\
\hline $\begin{array}{l}\text { Income to the city } \\
\text { Job opportunities }\end{array}$ & $6(33.33 \%)$ & $11(37.93 \%)$ \\
$\begin{array}{l}\text { Development of NA } \\
\text { Divulgation of NA as a } \\
\text { touristic city }\end{array}$ & $1(3.33 \%)$ & $2(13.79 \%)$ \\
$\begin{array}{l}\text { The city becomes more } \\
\text { festive }\end{array}$ & $5(16.67 \%)$ & $1(3.45 \%)$ \\
$\begin{array}{l}\text { Contact with different } \\
\text { cultures }\end{array}$ & $1(3.33 \%)$ & $1(3.45 \%)$ \\
$\begin{array}{l}\text { More tourists to NA } \\
\text { (=increased tourism in the } \\
\text { city) }\end{array}$ & $1(3.33 \%)$ & $2(6.9 \%)$ \\
$\begin{array}{l}\text { Acquire knowledge about the } \\
\text { Amazon }\end{array}$ & $1(3.33 \%)$ & - \\
$\begin{array}{l}\text { Benefits for those who work } \\
\text { with provisioning }\end{array}$ & $1(3.33 \%)$ & $2(6.9 \%)$ \\
$\begin{array}{l}\text { They do not represent benefits } \\
\text { Do not know the answer }\end{array}$ & $1(3.33 \%)$ & $1(3.45 \%)$ \\
\hline
\end{tabular}

* NA: Novo Airão.

The businessmen $(\mathrm{N}=21)$ mentioned six positive (16 citations) and nine negative (23 citations) aspects of the tourist activity of botos provisioning, while the inhabitants $(\mathrm{N}=24)$ mentioned six positive (22 citations) and 10 negative (21 citations) aspects (Table III). Some of the businessmen and inhabitants mentioned the existence of more than one negative and/or more than one positive point, which explains why the sampling size of the citations is higher than the number of interviewees.

Fifteen $(71.43 \% ; \mathrm{N}=21)$ of the businessmen perceive tourism as beneficial, and some also perceive the botos feeding tourism as beneficial (nine or $42.86 \% ; \mathrm{N}=21)$. Four $(16.67 \% ; \mathrm{N}=24)$ of the inhabitants perceive tourism as beneficial, and one $(4.17 \% ; \mathrm{N}=24)$ perceive the botos feeding tourism as beneficial.

Fifteen businessmen $(71.43 \% ; \mathrm{N}=21)$ and nine inhabitants $(37.5 \% ; \mathrm{N}=24)$ stated that botos provisioning is detrimental to the animals; two 
TABLE III

Positive and negative aspects of the activity of provisioning botos, as perceived by businessmen and inhabitants from Novo Airão.

\begin{tabular}{lcc}
\hline \multicolumn{1}{c}{ Positive aspects } & Businessmen & Inhabitants \\
\hline Increases tourism & $8(33.33 \%)$ & $8(27.59 \%)$ \\
The animals are fed & $1(4.17 \%)$ & $3(10.34 \%)$ \\
Therapy for the humans & - & $1(3.45 \%)$ \\
The owner profits with it & - & $6(20.69 \%)$ \\
Interaction with animals & $1(4.17 \%)$ & - \\
Income for inhabitants & $2(8.33 \%)$ & $2(6.9 \%)$ \\
Jobs for inhabitants & $2(8.33 \%)$ & $2(6.9 \%)$ \\
Increases environmental awareness & $2(8.33 \%)$ & - \\
No positive points & $3(12.5 \%)$ & $2(6.9 \%)$ \\
Does not know & $5(20.83 \%)$ & $5(17.24 \%)$ \\
\hline \multicolumn{1}{c}{ Negative aspects } & Businessmen & Inhabitants \\
\hline Cannot hunt anymore & $5(17.24 \%)$ & $5(15.15 \%)$ \\
It benefits only the owner & $9(31.03 \%)$ & $2(6.1 \%)$ \\
It harms the botos & $1(3.45 \%)$ & $2(6.1 \%)$ \\
Fish sold is frozen and not hygienically treated & $2(6.9 \%)$ & - \\
Lack of adequate structure & $1(3.45 \%)$ & $2(6.1 \%)$ \\
Transmission of animal diseases & - & $2(6.1 \%)$ \\
The botos will starve to death if not fed & $2(6.9 \%)$ & $1(3.03 \%)$ \\
Became aggressive in the last years & - & $2(6.1 \%)$ \\
The botos eat too much & $1(3.45 \%)$ & $1(3.03 \%)$ \\
The botos are evil & - & $2(6.1 \%)$ \\
Exploiting of the botos & - & $2(6.1 \%)$ \\
Similar to captivity & $1(3.45 \%)$ & - \\
No negative points & - & - \\
\hline & $(20.69 \%)$ & $5(15.15 \%)$ \\
\hline
\end{tabular}

businessmen $(9.52 \%)$ and 11 inhabitants (45.83\%) perceive provisioning as beneficial to the animals, and four businessmen $(19.05 \%)$ and four inhabitants $(16.67 \%)$ did not know whether provisioning is beneficial or harmful to the animals (Table IV). Some of the businessmen and inhabitants mentioned the existence of more than one negative and more than one positive point, which explains why the sampling size of the citations is higher than the number of interviewees.

Twenty $(95.24 \%$; $\mathrm{N}=21)$ of the businessmen and $19(79.17 \% ; \mathrm{N}=24)$ of the inhabitants stated that they think it is important to protect the botos (31 and 25 citations, respectively; Table V). One businessman (4.76\%) stated that it is not important to protect the botos, that he (the interviewee) does not care about the botos, and that he thought people could let the conditioned botos die. Two inhabitants $(8.33 \%)$ stated that it is not important to protect the botos. One of them stated that she (the interviewee) does not like botos, and the other stated that "there are too many botos". Three inhabitants (12.5\%) did not know the answer. Some of the businessmen and inhabitants mentioned the existence of more 
TABLE IV

Interference of the activity of provisioning specifically on the botos involved, according to the businessmen and inhabitants from Novo Airão.

\begin{tabular}{lcc}
\hline Perception about provisioning the botos & Businessmen & Inhabitants \\
\hline It causes behavioral alterations & $12(40 \%)$ & $7(21.87 \%)$ \\
They will die if not fed by humans anymore & $7(23.33 \%)$ & $2(6.25 \%)$ \\
("dependent") & $3(10 \%)$ & $3(9.37 \%)$ \\
They are similar to captive animals ("dependent”) & $2(6.67 \%)$ & $1(3.12 \%)$ \\
It makes the animals obese & - & $4(12.5 \%)$ \\
It makes the animals aggressive & $2(6.67 \%)$ & $11(34.37 \%)$ \\
It is good for them because they receive food & $4(13.33 \%)$ & $4(12.5 \%)$ \\
Do not know if it is beneficial or harmful & &
\end{tabular}

than one justification for the protection of the botos, which explains why the sampling size of the citations is higher than the number of interviewees.

When asked if it would be better to conduct botoswatching tourist activities without offering the botos food rewards while viewing the botos from a small boat or from land or maintain the current activity (interactions through provisioning), four businessmen (66.67\%; $\mathrm{N}=6)$ and eight inhabitants (61.54\%;
$\mathrm{N}=13$ ) stated that it would be better to conduct botos-watching tourist activities $(\mathrm{N}=5$ and $\mathrm{N}=8$ justifications, respectively), while two businessmen $(33.33 \%)$ and four inhabitants $(30.77 \%)$ stated that it would be better to maintain the provisioning (four justifications each). One inhabitant (7.69\%) did not know the answer (Table VI). It is worth noting that this question was introduced later in the study, so it presents a smaller number of samples.

TABLE V

Justifications of the businessmen and inhabitants of Novo Airão for their perception about why the botos should be protected.

\begin{tabular}{lcc}
\hline Justifications* & Businessmen & Inhabitants \\
\hline $\begin{array}{l}\text { Not only the botos but all the environment should } \\
\text { be protected }\end{array}$ & $8(25.81 \%)$ & $10(40 \%)$ \\
They promote tourism & $9(29.03 \%)$ & $3(12 \%)$ \\
They promote development & $3(9.68 \%)$ & $1(4 \%)$ \\
They are god's creation & $2(6.45 \%)$ & - \\
They do not harm anyone & $3(9.68 \%)$ & - \\
They help people (=income, jobs) & $1(3.22 \%)$ & - \\
They promote divulgation of NA (which also & $1(3.22 \%)$ & $1(4 \%)$ \\
promotes tourism) & $3(9.68 \%)$ & $2(8 \%)$ \\
They are a patrimony of NA & - & $2(8 \%)$ \\
It is important to protect botos as long as humans \\
are considered first
\end{tabular}

* NA: Novo Airão. 
TABLE VI

Justifications provided by businessmen and inhabitants of Novo Airão to alter the botos tourism in Novo Airão, from ongoing provisioning to boto watching, and to maintain provisioning.

\begin{tabular}{lcc}
\hline $\begin{array}{l}\text { Justifications to conduct boto } \\
\text { watching instead of provisioning }\end{array}$ & Businessmen & Inhabitants \\
\hline It is more interesting to watch natural behavior & $2(40 \%)$ & $2(25 \%)$ \\
It ('boto watching') is not exploitive of the animals & - & $1(25 \%)$ \\
as provisioning tourism is & - & $1(25 \%)$ \\
It is not normal for them to approach so much & $1(20 \%)$ & $1(25 \%)$ \\
Less contact with humans & - & $1(25 \%)$ \\
No disturbances to the animals & - & $1(25 \%)$ \\
They belong in the wild & $2(40 \%)$ & - \\
It is less risky for the tourists & Businessmen & $2(50 \%)$ \\
It does not create dependency on humans & $3(75 \%)$ & $1(25 \%)$ \\
\hline Justifications to maintain provisioning & - & $1(25 \%)$ \\
\hline Tourists can swim with and touch the animals & - & - \\
It is their natural behavior, to approach and interact & $1(25 \%)$ & \\
with humans & & \\
The owner profits with it The botos receive food & &
\end{tabular}

Eleven $(52.38 \% ; \mathrm{N}=21)$ of the businessmen believed that banning botos feeding tourism from Novo Airão would affect them negatively, and 10 $(47.62 \%)$ stated that banning botos feeding tourism would not affect them. No statistically significant difference was found in relation to the perception of the businessmen $(p=0.758)$. Twelve $(57.14 \%$; $\mathrm{N}=21$ ) of the businessmen believed that banning the botos feeding activity would also affect Novo Airão's economy, seven (33.33\%) believed it would not affect the economy, and two $(9.52 \%)$ did not know the answer. Despite the large differences observed in these percentages, no statistically significant difference was found in relation to the perception of the businessmen $(p=0.1211)$.

One $(4.17 \% ; N=24)$ of the inhabitants stated that banning the botos feeding would affect her life, $22(91.67 \%)$ believed it would not affect their lives, and one $(4.17 \%)$ did not know. The inhabitants significantly ( $p=0.000$ ) felt that the banning would not affect their lives. Nineteen inhabitants (79.17\%; $\mathrm{N}=24$ ) believed that banning botos feeding would affect Novo Airão's economy, whereas three
$(12.5 \%)$ believed it would not. Two inhabitants $(8.33 \%)$ did not know the answer. The inhabitants significantly $(p=0.000)$ believed that the banning would affect Novo Airão's economy.

When asked about their perception of the dispersion of the activity to other areas in the Amazon, four businessmen $(19.05 \% ; \mathrm{N}=21)$ and eight inhabitants $(33.33 \% ; \mathrm{N}=24)$ stated that dispersal of the botos provisioning activity to other areas would be positive, seven businessmen (33.33\%) and five inhabitants $(20.83 \%)$ stated that it would be negative, eight businessmen (38.09\%) and five inhabitants $(20.83 \%)$ showed indecision (they mentioned both positive and negative justifications), and two businessmen (9.52\%) and six inhabitants (25\%) did not know the answer (Table VII).

\section{DISCUSSION}

Although the owner of the floating structure where the interactions with the botos occur is native from the North Region and has been living in Novo Airão for some decades, most businessmen that lives in Novo Airão and profit from tourism in the city are recently 
TABLE VII

Justifications for the dispersion and the non-dispersion of the botos feeding tourism to other areas, accordingly to the businessmen and inhabitants of Novo Airão.

\begin{tabular}{lcc}
\hline Justifications for dispersion & Businessmen & Inhabitants \\
\hline Increases tourism in other areas & $9(81.82 \%)$ & $10(83.33 \%)$ \\
More animals will be fed & $2(18.18 \%)$ & $1(8.33 \%)$ \\
More cases of contact with nature & - & $1(8.33 \%)$ \\
\hline Justifications for non-dispersion & Businessmen & Inhabitants \\
\hline Dependency of more animals & $5(31.25 \%)$ & $5(31.25 \%)$ \\
Harming to more botos & $1(6.25 \%)$ & $1(6.25 \%)$ \\
Less tourists in Novo Airão & $4(25 \%)$ & $3(18.75 \%)$ \\
More impact to the environment & $2(12.5 \%)$ & - \\
The botos must be free animals & - & $3(18.75 \%)$ \\
They are like captive animals & - & $2(12.5 \%)$ \\
Disrespect with more animals & $3(18.75 \%)$ & $2(12.5 \%)$ \\
\hline
\end{tabular}

arrived outsiders, including foreigners (first author, pers. obs.). Most inhabitants of the north littoral of São Paulo State, where tourism is becoming the main economic activity and the traditional way of life is being suppressed, do not share the benefits of this industry, whereas the outsiders profit from it; in this region, one result of the implementation of the tourism industry is the transformation of the natural environment of the region by specific individuals who perceive nature as a consumption item (Luchiari 2000). In the case of Novo Airão, the incorporation of the region into the market economy and the urbanization process most likely compromises the region's sociocultural identity and the tradition that once ruled the relationship between man and nature, as Luchiari (2000) describes for her study.

Most of the businessmen believed that tourism is beneficial for them, but a much smaller percentage believed that the botos feeding tourism is also beneficial for them, suggesting that they perceive tourism, but not the botos feeding tourism, as having great importance. The inhabitants did not perceive tourism and, more specifically, the botos feeding tourism as beneficial for them, indicating that they perceive themselves as being totally excluded from the profits generated by these activities. However, despite believing that banning the botos feeding would not affect their lives, some inhabitants believed that it would affect Novo Airão's economy. Despite perceiving botos feeding as the main tourist attraction of the city, most respondents believed that it does not generate sufficient benefits to raise the city from poverty and effectively alter their lives, corroborating with F.C. Romagnoli's (unpublished data) work.

The difference between the results from the businessmen and the results from the inhabitants showed that a major part of the population of Novo Airão perceive themselves as excluded from the tourism industry, which apparently benefits only specific segments of the society (e.g., certain businessmen). In addition, only a small percentage of both the businessmen and inhabitants stated that they have family members working in tourism, and a much smaller percentage of family members work directly with the botos feeding tourism industry, differing from results achieved by Parsons et al. (2003), in which $47 \%$ of inhabitants from a community in rural West Scotland stated that they were professionally involved with local whalewatching activities. It is clear that tourism in Novo Airão is not achieving its objective of generating and multiplying job opportunities, as Cruz (1999) also observed in a community in Pará State, Brazil. 
The interviewees mentioned various negative and positive aspects of the activity of provisioning botos. The positive aspects included the economic benefits generated by the activity or the food that is offered to the animals. Despite their perception that this food is beneficial to the animals, the food has been described in the scientific literature as negatively affecting the animals. Although most of the interviewees stated that they think it is important to protect the botos and most businessmen stated that botos provisioning is detrimental to the animals, many inhabitants perceive artificial feeding as beneficial for them. Information about the negative consequences of the artificial feeding of wildlife is widely available, but accordingly to Fraser et al. (2006), the pervasiveness of fictional portrayals of dolphins in popular culture could make it difficult for the general public to distinguish fact from fiction and may pose a barrier to scientific education. According to those authors, the main characterizations of dolphins in popular media are that dolphins are peers and are of equal intelligence or at least capable of communicating with humans or helping humans; that they are representatives of peace, unconditional love, or idealized freedom in harmony with the natural order; as well as naive or innocent and subordinate and vulnerable; in addition of being superior to humans and associated with great power or intelligence. One interviewee believed that the dolphins benefit from having contact with humans in this case, and many especially believe that humans are helping the animals by feeding them, which is not correct from an animal welfare point of view.

Some interviewees also positively perceive the tourist activity of swimming with and touching the animals during interactions with the provisioned botos. In a study conducted in Tangalooma, Australia, Orams (2000) concluded that whale watching is not simply about getting close to whales and that operators do not need to get close to whales to satisfy their customers. It is important before conducting whale-watching activities to provide accurate infor- mation about the importance of respecting the natural behavior of the animals and their environment to allow the tourists participating in those activities to learn to enjoy watching natural, and not man-created, situations. We especially believe that feeding the botos as a tourist attraction activity disseminates the idea that feeding wildlife is correct conduct, constituting a form of anti-environmental education or environmental mis-education. In addition, the fact that some interviewees stated that they favor the dispersion of this activity to other areas because they believe it would increase tourism in those areas (even while recognizing it as an extremely impacting activity) is troubling.

Despite the erroneous (according to the scientific literature) perceptions described above, many interviewees perceived the activity of provisioning the botos as resulting in behavioral alterations (e.g., causing dependency), in addition to perceiving it as being exploitive to the botos and disrespectful to the animals and others. Those perceptions are in accordance with the scientific literature. According to Alves et al. (2013), the provisioning of botos in Novo Airão increases competition among the conditioned botos, that expect to be fed when interacts with humans, and alters their social behavior. Some interviewees perceive the dispersion of botos provisioning to other areas as negative because of its observable negative impacts. Others perceive provisioning as being similar to captivity, which is also in accordance with the scientific literature. Orams (1996) explicitly identifies the feeding of wildlife as an activity that falls between the semi-captive and wild categories. Conditioned botos cannot be considered truly wild because they are, at least in part, dependent on humans as captive and semi-captive animals.

Some interviewees (mostly inhabitants) stated that a positive aspect of the activity is their perception that the owner profits from the activity of provisioning, while others (mostly businessmen) stated that a negative aspect is their perception that only the owner profits from it. While the inhabitants perceived 
themselves as being completely excluded from the tourism industry, the businessmen apparently believed that the benefits should be shared with them and that not only the owner should benefit. In addition, many attempts to create new botos provisioning sites in Novo Airão have occurred in the past few years but failed due to discontinued food provisioning (according to Alves et al. In press, the botos conditioning is achieved by providing large amounts of food daily), prohibition by local conservation units (including the Anavilhanas National Park) managers and pressure by the owner of the floating structure where interactions occur to discontinue the interaction attempts (first author, personal observation), also reinforcing the fact that (at least) some businessmen are not satisfied with the perceived fact that only one person is able to profit directly from this activity.

According to the Brazilian Institute of Geography and Statistics (IBGE 2010), in 2003, $32.6 \%$ of the cities in Brazil had poverty indexes above $50 \%$, and $40.7 \%$ of the cities presented a Gini index (which measures economic inequality) above $40 \%$. Novo Airão presented a poverty index of $63.8 \%$ and a Gini index of $46 \%$; therefore, Novo Airão is not only among the poorest cities in Brazil but also presents a high level of inequality. The gross domestic product (GDP) per capita for Brazil in 2008 was R\$15,240.00, while in Novo Airão, it reached only $\mathrm{R} \$ 2,718.21$; agropecuary was responsible for $13.4 \%$ (average in Brazil was 5.66\%), industry was responsible for $12.7 \%$ (23.6\% in Brazil) and services (tourism included) were responsible for $71.3 \%$ (55.2\% in Brazil) of the GDP in 2008 (IBGE 2010 ), indicating the high importance of tourism to the economy of the city. The main source of income in Novo Airão is most likely tourism, and the feeding of the botos is perceived by the two groups as the main tourist attraction of the city, but according to the perceptions of most interviewees, the benefits are shared by very few. A discussion occurred at the Third World Congress of National Parks in Bali in 1962 concluded that the strategy of national parks and conservation units would only make sense with a decrease in consumption in the developed countries and an increase in the quality of life for the human population in developing countries. Without these phenomena, these human populations would be forced to overexploit the natural resources (Diegues 1998). Although Novo Airão presents such a high degree of poverty, the Anavilhanas National Park (or any other conservation unit) must not be responsible for solving the economic problems of the city and overexploit its natural resources. In Brazil, environmental issues are connected to social movements, and there is a generalized incomprehension of which issues are environmental and which represent political agendas and social demands (Olmos et al. 2001). Botos provisioning is now a political issue in the region and is treated as the solution to the poverty issue in Novo Airão, which we believe is not the case here.

In a general analysis, it is clear that both the businessmen and the inhabitants are aware of the negative aspects of this activity, and most of the positive aspects mentioned by the interviewees regard the economic benefits of this type of tourism, which could be achieved with a less detrimental activity. Although some businessmen interviewed here perceive themselves as dependent on this activity, our study showed that the population of Novo Airão would certainly understand any management decision that has to be taken by the responsible environmental agency, if conducted together with additional environmental education and proper justifications. In fact, some interviewees thought that the tourists possibly would be more attracted by activities that allowed them to watch the animals in natural situations. The interactions through provisioning conducted in Novo Airão are likely to be harmful to botos and potentially dangerous to humans (Alves et al. 2013). From an ethical perspective, the artificial feeding of wild dolphins causes avoidable and unnecessary harm (Donaldson et al. 2010), especially in a region with high ecotouristic potential 
such as the Amazon and, more specifically, the Anavilhanas archipelago region.

In addition, most tourists that visit Novo Airão today stay in the city for only a short period of a few hours; for the tourists, Novo Airão is just a shortterm visit (F.C. Romagnoli, unpublished data). It is of vital importance to create a better tourism management plan, aiming to create conditions that keep tourists longer in the Novo Airão region, which would increase the generation of income from tourist activities by utilizing the local tourism infrastructure such as restaurants, bars, lodges, hotels, and souvenir shops. This plan would contribute to a better distribution of the income generated by tourist activities, which currently benefits only a small percentage of the local population.

Based on the botos feeding tourism issue and its apparent interference in the local economy of Novo Airão, we propose mitigating measures to elaborate a sustainable management of the tourist activities in the region (BOX 1).

BOX 1. Management proposals to achieve sustainability in the tourism activity in Novo Airão, Central Amazon:

1. Creation or improvement of tourist attractions that produce less impact to the natural environment, such as the implementation of dolphin-watching (boto-watching) activities, in which the community will offer boat rides and trekking to sites where it is possible to observe river dolphins and offer visits to the river beaches, riverine traditional communities, and river bath sites, among others. Those activities should be always conducted together with educational and interpretational activities, in which qualified local members will provide and disseminate information about the Amazon environment, its fauna and flora and the human populations that inhabit it;
2. Conduct market evaluations (at the local, regional and national levels) through the creation of a touristic inventory by conducting surveys of the potential tourist attractions, infrastructure, socioeconomic diagnostic and local support capacity;

3. Develop a feeling of ownership in the local actors in the community so they can understand that they are part of the environment and that the conservation of the natural patrimony involves their participation;

4. Empower local actors to participate in the tourist activity, so the community will be able to present the environment to the tourists on their own;

5. Empower local actors to become the managers of activities related to community tourism;

6. Select local members that are better qualified to attend tourists;

7. Make it feasible to increase the visiting time of the tourists in the region through an increase in tourist offerings, such as the construction or improvement of adequate infrastructure involving local businesses (e.g., restaurants, lodges, hotels, souvenir shops, and general merchandise stores), improving the reception of the tourists by the local people, and improving access routes to the region and to the tourist attractions;

8. Programming the activities of the tourist attractions over a longer time period to increase the duration of time that the tourists stay in the region;

9. Elaboration of a code of conduct and the establishment of a support capacity in each of the natural attractions;

10.Elaboration of projects that divulge information about natural and man-made 
attractions (e.g., exhibits of traditional cuisine, songs, dances, religion, and economic history), while always respecting the limits and desires of the local actors.

The protection of nature allied with responsible and sustainable tourist activities presents the possibility of generating income in conjunction with conservation of the environment. For the case presented here, it is essential to create a tourism management plan to maintain the stability of the local economy such that the population is not dependent on the botos feeding tourism industry. A sustainable tourist activity should potentially help to maintain subsistence, strengthen the self-esteem of the local actors and valorize the cultural patrimony of the communities (Sansolo 2009). Therefore, tourism, in addition to being an economic activity, is also an agent of social development, cultural interchange and natural preservation (OMT 1993).

\section{CONCLUSIONS}

The economic benefits of this influential and controversial activity are apparently not shared among most of the population, and it is perceived as generating diverse negative effects. We conclude that if the activity was banned or modified into a less detrimental tourist activity, it would most likely not cause major impacts on the lives of the general population.

\section{ACKNOWLEDGMENTS}

The authors would like to thank Alison Wood at the Whale and Dolphin Conservation (WDC), Instituto Aqualie, the ICMBio staff from the Anavilhanas National Park, Marilda Medeiros and all the Restaurante Boto Cor-de-Rosa's staff, David Janiger, American Journal Experts and the anonymous reviewers of this journal. The authors would also like to acknowledge the Programa de Pós-Graduação em Meio Ambiente from the Universidade do Estado do Rio de Janeiro for the important support provided and the WDC for sponsoring this research. L.C.P.S. Alves is supported by Coordenação de Aperfeiçoamento de Pessoal de Nível Superior (CAPES). C. A. Zappes thanks CAPES for the concession of her post doctoral research grant (Process 87414) and FAPERJ (E-26/102.798/2011).

\section{RESUMO}

Botos-da-Amazônia (ou botos; Inia geoffrensis) são atualmente provisionados com alimentos para uso em atrações turísticas em cinco locais da Amazônia Brasileira. Apesar dos efeitos negativos associados com interações homem-golfinho já terem sido reportados, esta atividade foi recentemente regulamentada e licenciada no Parque Nacional de Anavilhanas, em Novo Airão, estado do Amazonas, Brasil. No presente trabalho apresentamos uma avaliação detalhada da percepção da comunidade local com relação aos possíveis impactos socioeconômicos deste turismo em Novo Airão. Em abril de 2011, 45 entrevistas foram realizadas com habitantes do município. Um pequeno segmento de Novo Airão possui a percepção de que são atualmente dependentes do turismo de alimentação artificial de botos. Apesar disso, os benefícios econômicos dessa atividade controversa aparentemente não são compartilhados entre a maior parte dos habitantes, e este turismo é percebido como gerando diversos efeitos negativos. Nós concluímos que se esta atividade fosse banida ou modificada para uma atividade turística menos impactante, esta ação provavelmente não iria afetar significativamente a vida da população em geral.

Palavras-chave: Amazônia, Parque Nacional de Anavilhanas, alimentação artificial, boto-da-Amazônia, Inia geoffrensis.

\section{REFERENCES}

Alves LCPS AND ANDRIOLO A. 2010. Caracterização preliminar do comércio ilegal de animais silvestres na feira livre do Bairro da Liberdade, Manacapuru, Estado do Amazonas, Brasil. Sitientibus Ser Ci Biol 10(2): 236-243. 
Alves LCPS, ANDriolo A, ORAMs MB AND AZEVEdo AF. 2011. The growth of "botos feeding tourism", a new tourism industry based on the boto (Amazon river dolphin) Inia geoffrensis in the Amazonas State, Brazil. Sitientibus Ser Ci Biol 11(1-2): 8-15.

Alves LCPS, ANDRIOLO A, ORAMS MB AND AZEVEDo AF. 2013. Resource defence and dominance hierarchy in the boto (Inia geoffrensis) during a provisioning program. Acta Ethol 16: 9-19.

Alves LCPS, SARTORI MA, ANDriolo A AND AZEVEdo AF. IN PRESS. Alimentação artificial de botos da Amazônia (Inia geoffrensis de Blainville, 1817) como atração turística e sua dispersão pela Amazônia Brasileira. Rev Bras Zooc.

BAILEY KD. 1982. Methods of Social Research. New York: Macmillan, $533 \mathrm{p}$.

BOGDAN RC AND BIKLEN SK. 1994. Investigação qualitativa em educação. Porto: Editora Porto, 336 p.

BRASIL. 1987. Lei $\mathrm{n}^{\circ}$ 7.643, de 18 de dezembro de 1987. Http://www.planalto.gov.br/ccivil_03/leis/L7643.htm, acessed May 02, 2012.

BRASIL. 2000. Lei ${ }^{\circ}$ 9985, de 18 de Julho de 2000 [Law number 9985, from July 18th, 2000]. Http://www.planalto.gov.br/ ccivil/leis/L9985.htm, acessed on February 12, 2012.

BRASIL. 2008. Decreto 6514 [Decreet 6514]. Http://www. leidireto.com.br/decreto-6514.html, April 28, 2012.

CONSTANTINE R. 2001. Increased avoidance of swimmers by wild bottlenose dolphins (Tursiops truncatus) due to longterm exposure to swim-with-dolphin tourism. Mar Mam Sci 17(4): 689-702.

CRUZ SHR. 1999. Turismo: a percepção dos residentes da Vila do Pesqueiro, município de Soure, Ilha de Marajó/ PA. In: FIGUEIREDO SL (Ed), O ecoturismo e a questão ambiental na Amazônia, Belém: UFPA/NAEA, p. 175-203.

DIEGUES ACS. 1998. O mito moderno da natureza intocada. São Paulo: Hucitec, 169 p.

Donaldson R, FINN H AND CALVER M. 2010. Illegal feeding increases risk of boat-strike and entanglement in Bottlenose Dolphins in Perth, Western Australia. Pac Cons Biol 16: 157-161.

Fraser J, Reiss D, Boyle P, LeMCKe K, Sickler J, ElliotT E, NeWMAN B AND GRUBER S. 2006. Dolphins in popular literature and media. Soc Anim 14(4): 321-349.

IBGE - INSTITUTO BRASILEIRO DE GEOGRAFIA E ESTATÍsTICA. 2010. Novo Airão. Http://www.ibge.gov.br/cidadesat/ topwindow.htm?1, acessed May 02, 2012.

ICMBIO - Instituto ChICO MENDES DE CONSERVAÇÃo DA Biodiversidade. 2010. Regras de Uso Público no Parque Nacional da Serra dos. Http://www.icmbio.gov.br/ parnaso/, acessed November 10, 2011.

KENDALL L. 2008. The conduct of qualitative interview: Research questions, methodological issues, and researching online. In: COIRO J ET AL. (Eds), Handbook of research on new literacies, New York: Lawrence Erlbaum Associates, p. 133-149.
LUCHIARI MTDP. 2000. Turismo e cultura caiçara no litoral norte paulista. In: RODRIGUES AB (Ed), Turismo, modernidade e globalização, São Paulo: Hucitec, p. 136-154.

MELo LG. 2004. Antropologia cultural, objetivo e método. In: MELO LG (Ed), Antropologia cultural: iniciação, teoria e temas, Petrópolis: Editora Vozes, p. 33-78.

OLMOS F ET AL. 2001. Correção política e biodiversidade: a crescente ameaça das "populações tradicionais" à Mata Atlântica. In: ALBUQUERQUE JLB ET AL. (Eds), Ornitologia e conservação: da ciência às estratégias, Tubarão: Editora Unisul, p. 279-312.

OMT - ORGANIZAÇÃo MuNDIAL DO TURISMO. 1993. Desenvolvimento de turismo sustentável: manual para organizadores. Report of the MICT/SETS and EMBRATUR, Brasília.

ORAMS MB. 1996. A conceptual model of tourist-wildlife interaction: The case for education as a management strategy. Aust Geogr 27(1): 39-51.

ORAMS MB. 2000. Tourists getting close to whales, is it what whale-watching is all about. Tourism Manage 21: 561-569.

ORAMS MB. 2002. Feeding wildlife as a tourism attraction: Issues and impacts. Tourism Manage 23(3): 281-293.

Parsons ECM, Warbuton CA, Woods-BAllard A, Hughes A AND JOHNSTON P. 2003. The value of conserving whales: the impacts of cetacean-related tourism on the economy of rural West Scotland. Aquat Conserv 13: 397-415.

Rocha D AND DeuSDARÁ B. 2005. Análise de conteúdo e análise do discurso: aproximações e afastamentos na (re) construção de uma trajetória. Alea: Estud Neolat 7: 305-322.

RYAN G AND BERNARD HR. 2000. Data management and analysis methods. In: DENZIN NK and LINCOLN YS (Eds), Handbook of qualitative research, London: Sage, p. 769-802.

SAMUELS A AND BEJDER L. 2004. Chronic interaction between humans and free-ranging bottlenose dolphins near Panama City Beach, Florida, USA. J Cetacean Res Manag 6(1): 69-77.

SANSOLO DG. 2009. Centralismo e participação na proteção da natureza e desenvolvimento do turismo no Brasil. In: BARTHOLO RET AL. (Eds), Turismo de base comunitária: diversidade de olhares e experiências brasileiras, Rio de Janeiro: Letra e Imagem, p. 122-137.

SANTOS MCO. 1997. Lone sociable bottlenose dolphin in Brazil: human fatality and management. Mar Mam Sci 13(2): 355-356.

SCHENSUL SL, SCHENSUL JJ AND LECOMPTE MD. 1999. Essential ethnographic methods: Observations, interviews and questionnaires. Walnut Creek: Altamira Press, 318 p.

SHANE SH, TEPLEY L AND COSTELlo L. 1993. Life threatening contact between a woman and a pilot whale captured on film. Mar Mam Sci 9(3): 331-336.

VIDAL MD. 2011. Botos e turistas em risco. Ciênc Hoje 47(281): 73-75.

WILKE M, Bossley M AND DOAK W. 2005. Managing human interactions with solitary dolphins. Aquat Mamm 31(4): 427-433. 